\title{
Application of AquaCrop in processing tomato growing and calculation of irrigation water
}

\author{
${ }^{1}$ Sándor Takács $-{ }^{2}$ Tibor Molnár $-{ }^{2}$ Erzsébet Csengeri $-{ }^{1}$ Tuan Anh Le \\ Szent István University, \\ ${ }^{1}$ Faculty of Agriculture and Environmental Sciences, Institute of Horticulture, Gödöllő \\ ${ }^{2}$ Faculty of Agricultural Sciences and Economics, Szarvas \\ takacs.sandor@mkk.szie.hu
}

\section{SUMMARY}

\begin{abstract}
The area and volume of processing tomato production is increasing in Hungary. Irrigation is crucial for processing tomato growing. To save water and energy, it is important to know exactly how much water is needed to reach the desirable quality and quantity. AquaCrop is a complex software, developed by FAO, which is able to calculate irrigation water needs, several stress factors and to predict yields. A field experiment was conducted in Szarvas in processing tomato stands, under different irrigation treatments. These were the following: fully irrigated plot with 100\% of evapotranspiration (ET) (calculated by AquaCrop), deficit irrigated plot with 50\% of ET (D) and control (K) plot with basic water supply was also examined. Dry yield, crop water stress index and soil moisture were compared to modelled data. The yields in the plots with different access to water were not outstanding in the experiment. The model overestimated the yields in every case, but the actual and modelled yields showed good correlation. AquaCrop detected stomatal closure percentages only in the unirrigated plot. These values were compared to CWSI - computed from leaf surface temperature data, collected by a thermal cam in July - and showed moderately strong correlation. This result suggests that Aquacrop simulates water stress not precisely and it is only applicable in the case of water scarcity. Soil moisture data of the three plots were only compared by means. The measured and modeled data did not differ in the case of $K$ and ET plots, but difference appeared in the D plot. The obtained results suggest that the use of AquaCrop for monitoring soil moisture and water stress has its limits when we apply the examined variables. In the case of dry yield prediction overestimation needs to be considered.
\end{abstract}

Keywords: dry yield, irrigation, stomatal closure, thermal cam, CWSI

\section{INTRODUCTION}

Processing tomato production shows continuous increase in the world. In Hungary, it reached the bottom in the 2010-2011 seasons, but due to the latest developments in processing industry, farmers grew processing tomato on 1500 ha in 2017 and produced 120-125 thousand tons yield. According to predictions, the production area can go up to 2000 ha in 2018 (FruitVeb 2017). Successful and sustainable production is not accomplishable without irrigation (Helyes et al. 1999). The cost of irrigation is a big part of the total growing cost, so it is important to know how much water exactly needed to reach the planned yield and quality. There are very simple methods for determining water demand of processing tomato, which depends on daily mean temperatures (Helyes 1990, Helyes et al. 2013). However, AquaCrop can be an option for farmers to determine that right amount of water to maintain healthy plants and get information about possible yields and different stresses (Vanuytrecht et al. 2014). This is an easy-to-use software, but still may be accurate enough to use it for research or growing purposes. Precise meteorological data is required for a good model. The software considers variables like soil (water balance, type, fertility), crop (species, growth, development, yield) and atmosphere (temperature, rainfall, evapotranspiration, $\mathrm{CO}_{2}$ concentration). The effect of groundwater table and type of irrigation can be also added to the simulation. The using of this software supported by two handbooks which are helping to understand the operation of the program and to learn how to build a model (Raes 2017, Raes and van
Gaelen 2017). Along with the precise computation of water demand, deficit irrigation (Bakr et al. 2017) or cut-off irrigation (Helyes et al. 2012) are also good ways to save water and energy. Calibration and validation of models are essential to increase accuracy and to find out its applicability.

When plant's access to water is limited or simply there is not enough water in the soil then plants must reduce their transpiration. Because of that, they must close stomas and due to this the temperature of the foliage is increasing. This gives us the opportunity to monitor plant water stress through leaf surface temperature (Bates and Hall 1981, Helyes et al. 2006, Böcs et al. 2009). There are several possibilities that quantify plant water stress from leaf surface temperature. The simplest index to use is Stress Degree Day (SDD), that is computed as a difference of foliage temperature and air temperature (Jackson et al. 1977, Idso et al. 1981, Helyes et al. 2006). It is affected by cloud cover and it is not considering vapour pressure deficit or relative humidity. Crop Water Stress Index (CWSI) (Jackson et al. 1981) is more developed. To compute this index, we do not need any additional meteorological measurement at all. However, it considers the external effects of the near environment on the examined plant during the temperature measurement of artificial wet and dry reference surfaces (Jones 1999). Infrared thermography gives a good opportunity to detect crop water stress using these indices (Jones 2004).

Our goal in this study was to simulate a processing tomato season in AquaCrop and compare the modelled data to actual measurements. To accomplish this, we 
retrieved dry yield, soil moisture and water stress inducing stomatal closure from the model.

\section{MATERIALS AND METHODS}

A field experiment was conducted in Szarvas, south-east Hungary on the experimental farm of Szent István University in 2017. The size of the experimental area was $38 \times 104 \mathrm{~m}(\sim 0.4 \mathrm{ha})$ and it was divided into three, almost equal pieces for the different water application treatments. We used AcuaCrop v5.0 (Steduto et al. 2012) to determine the water demand of plants and to run the full season model. The software calculates evapotranspiration according to the FAO Penman-Monteith method (Allen et al. 1998) that considers even the development state of plants. One plot of the three was irrigated with $100 \%$ of the potential evapotranspiration (ET) computed with the software. One other plot was irrigated with $50 \%$ of ET (D) and the third plot was the control $(\mathrm{K})$ with basic water supply at transplanting and fertilization events. The amount of water available to plants was $467 \mathrm{~mm}$ (ET), $326 \mathrm{~mm}(\mathrm{D})$ and $186 \mathrm{~mm}(\mathrm{~K})$ respectively, during the season. The sprinkler irrigation was performed with a precision center pivot system (VRI iS), two times per week. The shapes of these plots and different irrigation rates were planned with Valley VRI 8.46 software in the beginning of the season. Irrigation was suspended 19 days before harvest.

The experiment was placed on clay-loam soil. The texture of the upper $35 \mathrm{~cm}$ layer is composed of $37 \%$ clay, $29.4 \%$ sand and $33.6 \%$ silt. According to the soil survey it contains $3 \%$ humus and the $\mathrm{pH}$ is 6.68 . The quantity of macro elements are $9.87 \mathrm{mg} \mathrm{kg}^{-1}\left(\mathrm{NO}_{3}{ }^{-} \mathrm{N}+\right.$ $\left.\mathrm{NO}_{2}^{-} \mathrm{N}\right),>700 \mathrm{mg} \mathrm{kg}^{-1}\left(\mathrm{P}_{2} \mathrm{O}_{5}\right)$ and $>600 \mathrm{mg} \mathrm{kg}^{-1}\left(\mathrm{~K}_{2} \mathrm{O}\right)$. Meteorological data were gathered by a meteorological station installed nearby the field (temperature, rain, wind speed, relative humidity). Soil moisture was monitored in every plot, during the whole experiment in the upper $15 \mathrm{~cm}$ level with a Trime-fm soil moisture probe (IMKO Micromodultechnik GmbH, Ettlingen, Germany) two times a week. The data was interpolated for the days between measurements. These measured values were compared to the modelled data. AquaCrop compute soil moisture for $5 \mathrm{~cm}$ and $15 \mathrm{~cm}$ level below ground, so we took the mean of values from these two depths for the comparison. This examination relates only to July.

UG812J F1 hybrid was planted out on $9^{\text {th }}$ of May to single row style $(140 \times 20 \mathrm{~cm})$. There was single harvest dates on $17^{\text {th }}$ of August manually, that involved the evaluation of fruit (red ripened, green and nonmarketable fruits) yield and parameters (aboveground fresh biomass, number of fruits, fruit weight and soluble solids content), when 10 plants were sampled per 2 times from each treatment. We measured the aboveground fresh biomass and the total fruit yield. We measured soluble solids content (SS) of the fruits with a Digital Refractometer Krüss DR 201-95 (Krüss Optronic, Hamburg, Germany), and calculated total solids (TS) according to the literature (Patané and Cosentino 2010, Patanè et al. 2011) to determine actual dry yield for the comparison with modelled yield. The AquaCrop software is able to model the percent water stress inducing stomatal closure (Ssto) on a daily basis. These percentage values were compared to Crop Water Stress Index (CWSI) values. We had been conducting leaf surface temperature measurements only in July. Due to rainy days we collected data for 28 days. To calculate CWSI (Jones 1999), temperature from dry and wet reference surfaces were also gathered $\left(\mathrm{T}_{\text {leaf }}-\mathrm{T}_{\text {wet }}\right) /\left(\mathrm{T}_{\text {dry }}-\mathrm{T}_{\text {wet }}\right)$. These kinds of data were collected by a FLIR One for Android thermal cam (FLIR Systems, Wilsonville, Oregon, USA). The pictures were processed by FLIR Tools 6.3 software.

Statistical tests were performed in R x64 3.4.0 (R Development Core Team 2008) with Rcommander. Pearson's correlation tests were used to see connection between Ssto and CWSI and between the modelled and the actual yields. Welch test was applied to investigate differences between the modelled and the measured soil moisture data.

\section{RESULTS}

\section{Meteorology and irrigation}

According to meteorological measurements (Figure 1) the mean temperature of the whole season was $21.9^{\circ} \mathrm{C}$. The mean relative humidity was $64.1 \%$ and the total amount of rainfall was $146.3 \mathrm{~mm}$. Control was irrigated four times during season at the time of transplanting and at the time of fertilization. These amounts were $15,10,8$ and $8 \mathrm{~mm}$, respectively. Due to these the total water amounts were the following in the treatments: $186(\mathrm{~K}), 326$ (D) and 467 $\mathrm{mm}$ (ET). After the irrigation was terminated on $29^{\text {th }}$ July, $30.3 \mathrm{~mm}$ rainfall was measured.

\section{Yields}

At the time of harvest, we collected two samples from each differently irrigated plot, so we fitted six measured yield values to the three modelled values (Figure 2). As a result of Pearson's correlation test we found out that the modelled and the actual data was correlating $(\mathrm{p}<0.05)$. The correlation coefficient is strong $(\mathrm{r}=0.82)$ and shows positive linear correlation. The modelled yields were higher than the harvested yields in every case. Harvested yield in the ET treatment was $72 \%$ of the modelled yield, $64 \%$ in the D treatment and only $62 \%$ in the control.

\section{Water stress}

In the AquaCrop simulation, water stress inducing stomatal closure appeared only for the simulation of the control. The fully irrigated plot did not show stomatal closure percentages at all and it could not detect notable stress in the deficit irrigation plot either. Due to this we compared data of the control only, which is shown on Figure 3. According to the result of the Pearson's correlation test, there was correlation between the modelled and the measured stress data $(\mathrm{p}<0.01)$. We found moderately strong positive linear correlation $(\mathrm{r}=0.62)$. 
Figure 1: Meteorological data for the processing tomato season and the cumulated irrigation water amounts per treatment (Szarvas, 2017)

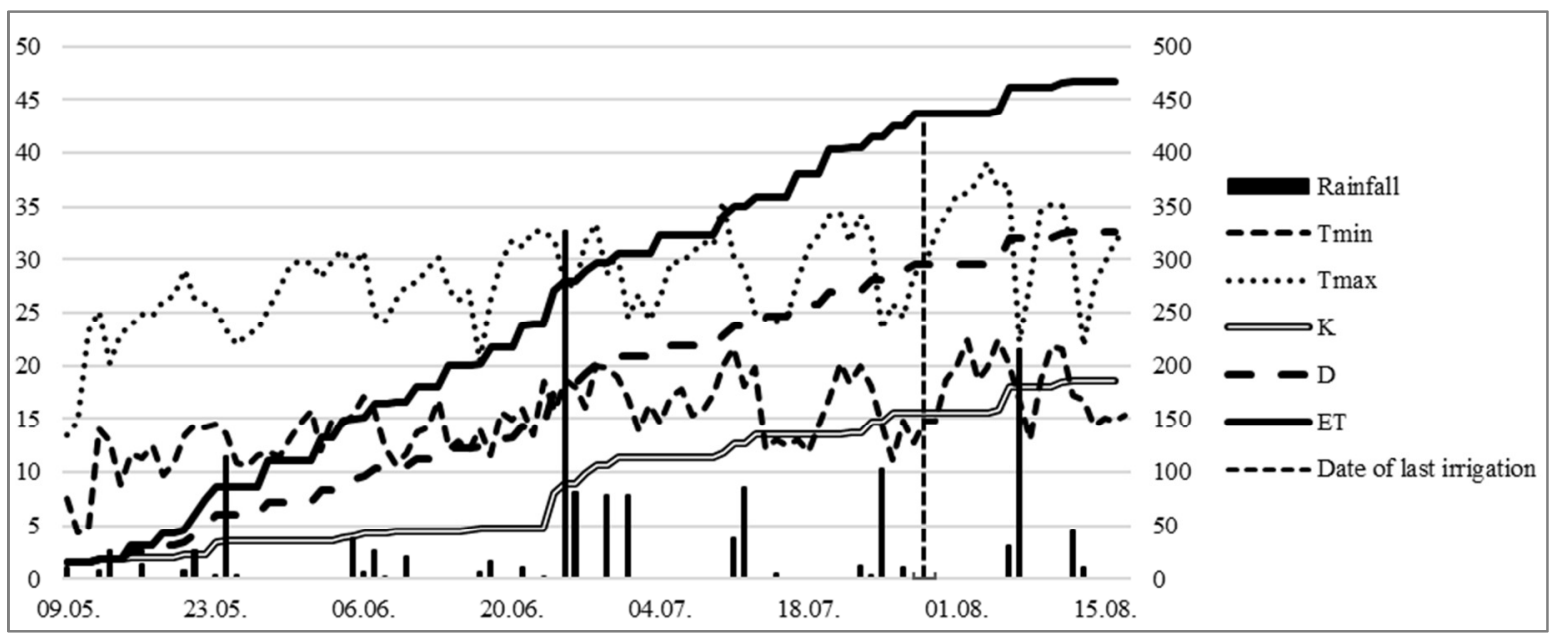

Figure 2: Correlation between the modelled dry yields and the harvested dry yields

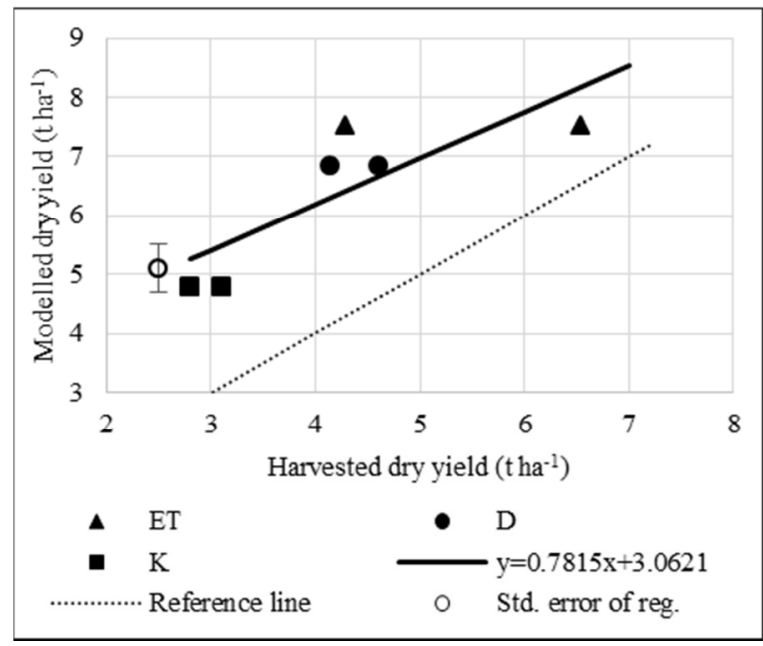

Note: $\mathrm{n}=6 ; \mathrm{r}=0.82 ; \mathrm{p}<0.05$.

Figure 3: Correlation between stomatal closure percentage (modelled) and crop water stress index (computed from measured data)

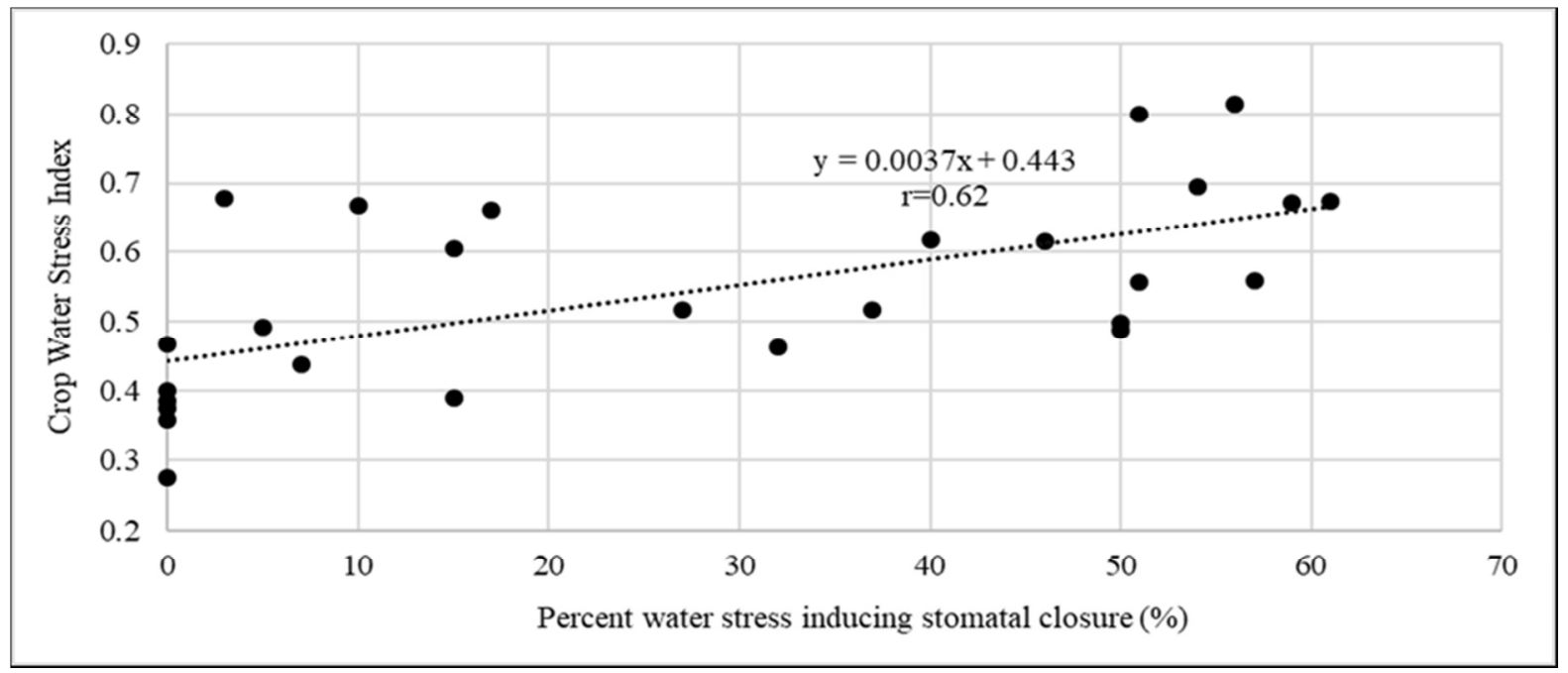

Note: $\mathrm{n}=28 ; \mathrm{r}=0.62 ; \mathrm{p}<0.01$. 


\section{Soil moisture}

Since AquaCrop calculates soil moisture data also, we could compare that with the measured data. This comparison relates to all the three plots, but only for July. In the cases of control and fully irrigated plots the Welch test was not able to differentiate the measured and the modelled data $(\mathrm{p}>0.05)$. However, the modelled and the measured data was not similar in the deficit irrigated plot $(\mathrm{p}<0.05)$. The graph shows how the modelled data followed the measured data during the month (Figure 4).

Figure 4: Modelled and measured soil moisture throughout July in the fully irrigated plot

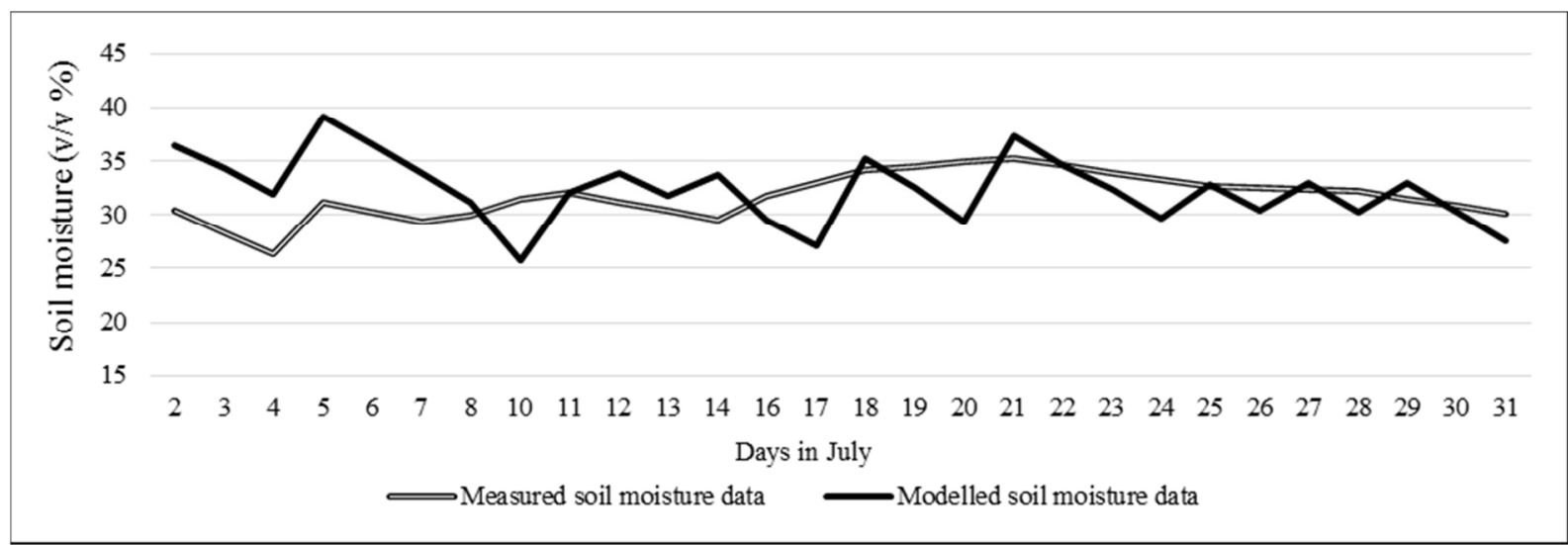

\section{CONCLUSION AND DISCUSSION}

\section{Meteorology and irrigation}

This little amount of rain, that occurred in the 2017 season is not enough for sufficient and sustainable processing tomato growing, so the irrigation was necessary. Precise and site-specific data is needed when we want to determine irrigation water demand with AquaCrop or anything else that based on computing potential evapotranspiration.

\section{Yields}

Considering the cultivar and irrigation, these yields are not outstanding. That is the explanation why the modelled yields were always above the harvested yields. Moreover, Montoya and Coworkers (2016) also faced with overestimation when they validated the model for potato. Katerji et al. (2013) found overestimation of corn yield and underestimation of evapotranspiration. By the two highest yields, there is relatively big difference between the two harvested yields, even if these were both harvested from the fully irrigated plot. The explanation for this phenomenon is obviously not connected to the water application. The cause can rather be soil related. The correlation between the modelled and harvested yields must be affected by the low amount of data points. Considering this and the good correlation, AquaCrop can be a good option to predict the expectable dry yields in processing tomato, but it definitely needs further data for thorough investigation. That is very important from the farmers point of view for irrigation management planning, since the rate of irrigation water saving can be higher than yield reduction, as it had been found in potato (Linker et al. 2016). The processing industry's interest is pointing at the prediction of dry yields also for better using the capacities.

\section{Water stress}

It is not a surprise that stomatal closure did not appear according to the simulation of fully irrigated treatment. However, we expected at least low stomatal closure percentages in the deficit irrigated plot, but it occurred only in the last two days of the month. Despite the simulated low water stress, the yield was less in the deficit irrigated plot. So, if the cause was water stress it could happen out of the examined period. The found correlation between CWSI values and modelled Ssto values is promising for monitor water stress of tomato plants, especially under water stressed conditions.

\section{Soil moisture}

Application of AquaCrop to soil moisture monitoring is promising, but it requires further study of whole season soil moisture monitoring and more detailed evaluation to draw solid conclusions. Moreover its inaccuracy in simulating soil water and evapotranspiration is found by others (Pereira et al. 2015). The reason of the smoother line of measured data must be the interpolation and obviously carries errors, but two measurements in a week is satisfying for this examination. We must note here, that we did not use any boundary conditions at the simulation, which could affect the modelled data, especially in the beginning of simulation.

\section{ACKNOWLEDGEMENT}

This study was supported by the ÚNKP-17-3I/SZIE-1 New National Excellence Program of the Ministry of Human Capacities and GINOP 2.2.1-152016-00003. The publication is supported by the EFOP-3.6.3-VEKOP-16-2017-00008 and EFOP3.6.1-16-2016-0016 projects. These projects are cofinanced by the European Union and the European Social Fund. 


\section{REFERENCES}

Allen, R. G.-Pereira, L. S.-Raes, D.-Smith, M.-Ab, W. (1998): Crop evapotranspiration - Guidelines for computing crop water requirements. FAO Irrigation and drainage paper 56. 1-15.

Bakr, J. A.-Daood, H.-Pék, Z.-Helyes, L.-Posta, K. (2017): Yield and Quality of Mycorrhized Processing Tomato Under Water Scarcity. Applied Ecology and Environmental Research. 15. 1: 401-413.

Bates, L. M.-Hall, A. E. (1981): Stomatal Closure with Soil Water Depletion Not Associated with Changes in Bulk Leaf Water Status. Oecologia. 50: 62-65.

Bőcs, A.-Pék, Z.-Helyes, L.-Neményi, A.-Komjáthy, L. (2009): Effect of Water Supply on Canopy Temperature and Yield of Processing Tomato. Cereal Res. Commun. 37: 113-116.

FruitVeb (2017): A jövő évben jelentősen bővülhet az ipari paradicsom termőterülete. https://fruitveb.hu/jovo-evbenjelentosen-bovulhet-az-ipari-paradicsom-termoterulete/

Helyes, L. (1990): Relations among the water supply, foliage temperature and the yield of tomato. Acta horticulturae. 227: $115-121$.

Helyes, L.-Lugasi, A.-Pék, Z. (2012): Effect of irrigation on processing tomato yield and antioxidant components. Turkish Journal of Agriculture and Forestry. 36. 6: 702-709.

Helyes, L.-Neményi, A.-Pék, Z.-Berki, M.-Daood, H. G. (2013): Effect of variety and water supply on phytochemical (phenolics and carotenoids) content and composition of processing tomato. Acta Horticulturae. 971: 93-98.

Helyes, L.-Pék, Z.-McMichael, B. (2006): Relationship between the stress degree day index and biomass production and the effect and timing of irrigation in snap bean (Phaseolus vulgaris var. nanus) stands: results of a long term expeiments. Acta Botanica Hungarica. 48. 3-4: 311-321.

Helyes, L.-Varga, G.-Dimény, J.-Pék, Z. (1999): The simultaneous effect of variety, irrigation and weather on tomato yield. Acta Horticulturae. 487: 499-504.

Idso, S. B.-Jackson, R. D.-Pinter, P. J.-Reginato, R. J.-Hatfield, J. L. (1981): Normalizing the stress-degree-day parameter for environmental variability. Agricultural Meteorology. 24: 4555.

Jackson, R. D.-Idso, S. B.-Reginato, R. J.-Pinter, J. P. J. (1981): Canopy temperature as a crop water stress indicator. Water resources research. 17. 4: 1133-1138.

Jackson, R. D.-Reginato, R. J.-Idso, S. B. (1977): Wheat canopy temperature: A practical tool for evaluating water requirements. Water Resources Research. 13. 3: 651-656.

Jones, H. G. (1999): Use of infrared thermometry for estimation of stomatal conductance as a possible aid to irrigation scheduling. Agricultural and Forest Meteorology. 95. 3: 139-149.
Jones, H. G. (2004): Application of Thermal Imaging and Infrared Sensing in Plant Physiology and Ecophysiology. Advances in Botanical Research. 41: 107-163.

Katerji, N.-Campi, P.-Mastrorilli, M. (2013): Productivity, evapotranspiration, and water use efficiency of corn and tomato crops simulated by AquaCrop under contrasting water stress conditions in the Mediterranean region. Agricultural Water Management. 130: 14-26.

Linker, R.-Ioslovich, I.-Sylaios, G.-Plauborg, F.-Battilani, A. (2016): Optimal model-based deficit irrigation scheduling using AquaCrop: A simulation study with cotton, potato and tomato. Agricultural Water Management. 163: 236-243.

Montoya, F.-Camargo, D.-Ortega, J. F.-Córcoles, J. I.-Domínguez, A. (2016): Evaluation of Aquacrop model for a potato crop under different irrigation conditions. Agricultural Water Management. 164: 267-280.

Patané, C.-Cosentino, S. L. (2010): Effects of soil water deficit on yield and quality of processing tomato under a Mediterranean climate. Agricultural Water Management. 97. 1: 131-138.

Patanè, C.-Tringali, S.-Sortino, O. (2011): Effects of deficit irrigation on biomass, yield, water productivity and fruit quality of processing tomato under semi-arid Mediterranean climate conditions. Scientia Horticulturae. 129. 4: 590-596.

Pereira, L. S.-Paredes, P.-Rodrigues, G. C.-Neves, M. (2015): Modeling malt barley water use and evapotranspiration partitioning in two contrasting rainfall years. Assessing AquaCrop and SIMDualKc models. Agricultural Water Management. 159: 239-254.

R Development Core Team (2008). R: A language and environment for statistical computing. $\mathrm{R}$ Foundation for Statistical Computing, Vienna, Austria. http://www.R-project.org

Raes, D. (2017): AquaCrop training handbooks Book I Understanding AquaCrop. Rome: Food and Agriculture Organization of the United Nations. 50.

Raes, D.-van Gaelen, H. (2017): AquaCrop Training Handbook Book II. Rome. Food and Agriculture Organization of the United Nations. 109.

Steduto, P.-Hsiao, T. C.-Fereres, E.-Raes, D. (2012): Crop yield response to water. In Fao Irrigation and Drainage Paper 66. 192-201.

Vanuytrecht, E.-Raes, D.-Steduto, P.-Hsiao, T. C.-Fereres, E.Heng, L. K.-Garcia Vila, M.-Mejias Moreno, P. (2014): AquaCrop: FAO's crop water productivity and yield response model. Environmental Modelling \& Software. 62: 351-360. 